\title{
Serious Humor about the Egyptian Nuclear Program: A Pragmatic Analysis of Facebook Posts
}

\author{
May Samir El Falaky
}

Arab Academy for Science and Technology

College of Language and Communication

Egypt, Cairo

maismf@hotmail.com

\section{ABSTRACT}

The present study aims at investigating Egyptian humor towards the Egyptian Nuclear Program. Based on ninety trending Facebook posts (liked by at least 1000 users), both the Cooperative Principle and the General Theory of Verbal Humor are applied. The data are analyzed qualitatively and quantitatively to measure the societal evaluation of the Nuclear Program which is part of the governmental reform plan. The findings suggest that people's practices of humor on Facebook could reveal their evaluative perception and the ideological discernment of the Nuclear Program along with other sociological phenomena.

Such practices of humor explicate how the Facebook posts reflect the people's perception and evaluation of the prospective effect of the Nuclear Program on the Egyptian society.

Key words:

Humor; Cooperative Principles; maxims; General Theory of Verbal Humor; Stereotyping; knowledge resources 
Serious Humor about the Egyptian Nuclear Program: A Pragmatic Analysis of Facebook Posts

\title{
Serious Humor about the Egyptian Nuclear Program: A Pragmatic Analysis of Facebook Posts
}

\author{
May Samir El Falaky
}

Arab Academy for Science and Technology

College of Language and Communication

Egypt, Cairo

\section{INTRODUCTION}

The advent of new technology and the proliferation of Facebook posts have assisted social members to criticize societal and economic issues.. Thus, studying humor from the national projects perspective enables decision makers to trace and detect the problematic issues in a given context. This study employs the Cooperative Principle (CP) with its four maxims, namely, Quantity, Quality, Manner, Relation and the General Theory of verbal Humor (GTVH) with its six Knowledge Resources (KR), namely, script opposition (SO), logical mechanism (LM), situation (SI), target (TA), narrative strategy (NS), and language (LA).

This study aims at probing into the linguistic choices of the opposition of scripts which are responsible for the creation of humor. The two theories are utilized to disassemble the linguistic choices in the humorous posts to define their intended message and target audience.

\subsection{Why Humor?}

It is noteworthy that the study of humorous texts attracts scholars to elucidate their linguistic nature and implications. Humor is a pragmatic process used to trigger response from the audience. That is, some studies are dedicated to the effect of humor on participants on problem solving and cleverness (Branchini et.al, 2017; Canestrari et.al 2017). Research on humor, also, discusses both pragmatic and sociolinguistic aspects, where gender and humor are interrelated (Heidari-Shahreza, 2017). Heidari-Shahreza (2017) confers gender-based hegemonic male-dominated view of humor

ELLS Vol.9 No.I (212) SPU December 2018 
and the degree of gender bias for the target audience, which, in turn, is seen as a reflection of societies in its intricate networks. A body of literature elucidates semantic-pragmatic approaches to how humorous discourse advances to achieve its socio-economic and political intents (Thielemann, 2010; Vazquez, 2016; Toribio, 2017; Aguza, 2017).

Still, online humorous discourse is a form of non-literal language used in computer-mediated discourse to provide judgments and evaluations on certain issues (Karpinska-Krakowiak and Modlinski, 2018). Similarly, Kellner (2017) argues that investigating the language of humor in online and digital discourses can provide a greater perception of this linguistic tool. Pickering et al. (2018) likewise inspect humor discourse in the virtual environment, where participants are not companions, and whose shared factor is only a well-known topic. With their main focus on the impact of emotions on maintaining relations, Pickering et al. conceived the linguistic aspects that enabled them to achieve the communicative roles of each user.

\subsection{Egypt's Nuclear Program: An Overview}

Dated back to the establishment of the Atomic Energy Commission in 1955, the Egyptian Nuclear Program is not a new idea. Egypt has been seeking to rely on other renewal and green energy sources other than fuel and other traditional sources of power (Egyptian Atomic Energy Authority, n.d.). Since the establishment of the Nuclear Power Plants Authority and the Supreme Council of Energy in 1976, the Egyptian government is taking slow steps in supporting the project despite the urgent need of alternative energy resources.

Various announcements and declarations about the establishment of the nuclear reactor were made, but its commencement is still underway. Despite the incessant releases about the importance of shifting to clean sources of energy, nuclear energy and technology, use of nuclear technology, the progress in

\section{ELLS VoI.9 No.I (213) SPU December 2018}


the project is deemed to be slow-paced by the majority of the Egyptians.

\section{LITERATURE REVIEW}

Seated on the nexus of different theoretical frameworks, humor and language of irony interlace to divulge beliefs. Plato's Superiority Theories, for instance, suggest that laughing occurs when we maximize the inferiority of the other and grandiose the feeling of self-superiority over other people (Monro, 1951; Morreal, 1987; Bergson; 1911). Release Theory, similarly, explains how language users free themselves of constraints in mimicking the reality and their taboos, sexuality aggression and violence. According to the Release Theory, both psychological and physiological reasons are ascribed to the laughter process and its emotional involvements (Minsky, 1980). On the other hand, Incongruity Theories are cognitively-based and they are concerned with the mental processing rather than the external influence of the humor and its entailed laughter. That is, incongruity and unexpectations are the main reason for humor (Morreal, 1987, 1989; Forabosco, 1992).

Other theories of humor have emerged and developed to examine the linguistic competence of both the speakers and the hearers. Such linguistic-based theories are exemplified in the Semantic Script Theory of Humor (SSTH) (Raskin, 1985), where the main focus is on the linguistic exchanges of semantic scripts. Defined by Raskin (1985), semantic scripts represent the speaker's knowledge of a certain event in his world. To Raskin, words and lexis are 'interconnected' seeking to describe the surroundings. Humor emerges when there is an overlap between the linguistic choices and the natural scripts.

\subsection{General Theory of Verbal Humor}

A revised theory of SSTH, GTVH is developed to explore verbal humor and to probe deeper than the surface structure of an utterance in order to understand what's really being conveyed (Attardo and Raskin, 1991; Attardo, 2001).

\section{ELLS Vol.9 No.I (214) SPU December 2018}


Whereas the SSTH was a semantic theory of humor, the GTVH is a linguistic theory "at large"-- that is, it includes other areas of linguistics as well, including most notably textual linguistics, the theory of narrativity, and pragmatics. (Attardo, 2001, p.22)

According to Attardo (2001), humorous texts have certain structures and must include what he calls 'punch-line' or 'jab line'. Both are semantically the same but they are different in their position, where the former terminates the joke and the latter occurs in any position except its end. According to Attardo (2001), punchlines disrupt the flow of humorous texts, while jab lines are catalyst for its development if not its plot.

Within the GTVH framework of analysis, Attardo and Raskin (1991) define six KRs to account for the humorous effect of a text. That is, the theory proceeds within a set of information to describe humorous texts. That is, all the six KRs must be present in the following hierarchy:

(a) The SO: describing humorous texts within two different and opposed scripts.

(b) The LM: basing the humor on logical order and coherent description that results in script opposition.

(c) The SI: the circumstances surrounding the joke including the objects, participants, activities, etc.

(d) The TA: Who is ridiculed by humor (i.e., the butt of humor) involving groups, individuals, institutions, etc.

(e) The NS: The narrative organization of a humorous text, whether simple narrative, dialogue, or a riddle).

(f) The LA: words and lexical choices used to verbalize the humor in a text.

\section{$\begin{array}{llllll}\text { ELLS Vol.9 No.I } & \text { (215) SPU December } 2018\end{array}$}


Such KRs, according to Attardo and Raskin (1991), provide the necessary information for coding and decoding the humorous elements in the texts.First and foremost, script is the focal point of GTVH. Script repertoire envisages the knowledge about the world and it is only through such manifestation of scripts that communication is made possible. It is when two scripts oppose each other, humor is triggered.

What triggers the script is what Attardo (2001) calls 'lexamatic handle'. Such lexical items activate the script and contain the required information about how the whole script context actually is. According to GTVH, oppositions of scripts take many forms, such as real/unreal, actual/non-actual, normal/abnormal, good/bad, and life/death etc. To switch from one script to another, there must be textual elements that switch between the alternative scripts.

While SO and LM are the abstract parameters in GTVH, both NS and SI are tangible and can be evaluated in the text. The TA is stereotyped objects, people, individuals, institutions. Ideology controls the choice of targets and is highly reflected by it. The LA is the KR that comprises "....all choices at the phonetic, phonological, morphophonemic, morphological, lexical, syntactic, semantic, and pragmatic levels of language" (Attardo and Raskin, 1991, p.298). LA is also responsible for the positioning of both 'punch-line' (coming at the end of the joke) and 'jag line' (integral element in initial or middle position of the joke)

\subsection{The Cooperative Principle (CP)}

The CP is proposed by Paul Grice (1975) to explore interpersonal communication and how people exchange messages in conversations. According to $\mathrm{CP}$ the degree of adherence to the four maxims is responsible for the degree of success of the intended exchange. Grice states that implicature rises when one of the following four maxims is violated:

Maxim of Quality: Be informative; don't say what you believe to be false or untrue 


\section{May Samir El Falaky}

Maxim of Quantity: Provide true information; don't say

more or less than is required

Maxim or manner: Be clear, brief and orderly

Maxim of relation: Be relevant

Violating one or more of these maxims results in what he calls 'implicature', hence the hearers have to look beyond what is actually stated in the conversation. Using implicature is quintessential to the language of humor; thus, both theories are assimilated in the analysis of humor discourses.

Raskin (1979) reiterates the interconnection between Scripts and the Conversational Implicature postulated in the Gricean Maxims. Such interconnection is reinforced by the participant's role to infer the humorous discourse and decode its linguistic components.

\section{METHODOLOGY}

The study is capitalized on 90 Facebook posts, where the following query of the word 'nuclear' and its collocations are used to extract the analyzed posts:

$$
\text { نووي؛ طاقة نووية؛ مفاعل نووي؛ مشروع نووي }
$$

In the search section of Facebook, the above words with all their possible punctuations are inserted and the resulting posts are filtered

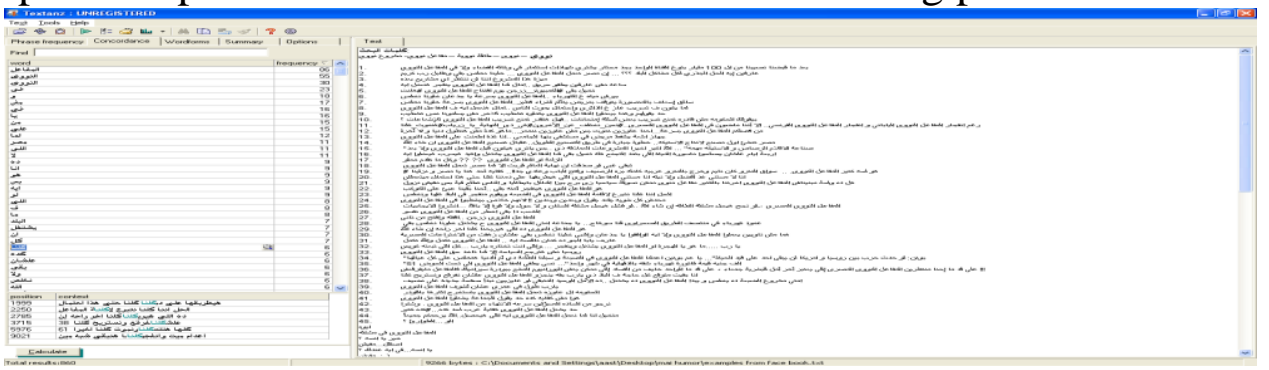

Figure (1) Textanz [Screen shot- Headword Freouencv]

ELLS Vol.9 No.I (217) SPU December 2018


in terms of their meaning. Using concordance software, the topics of the posts are identified and the posts are classified according to the emerging themes.

To achieve its intents, the study utilizes the computer software TEXTANZ in the analysis of the Facebook posts. The software is helpful in making concordances and automated word lists which is discerned to yield better insights into the text, especially when analyzing medium-sized texts as in the current study. The specific choice of TEXTANZ is ascribed to the nature of the Arabic characters - coding, which are hardly identified in similar concordance software.The program displays all head words and it calculates the frequency of all words and the quiries made about specifc phrases. Word and phrase frequencies, in addition to collocations, help in providing a quantitative approaching to the corpus at hand (See Figure 2).

The importance of collocations lies in contextualizing the key words and identifying the themes of the posts. Some verbs, verbal nouns and other lexis reflect the attitudes towards a certain topic, hence reinforcing the writer's point of view. Figure (2) shows an instance of the concordance of the verb خلونا with its pre and post texts.

The study, then, employs two analytical tools, namely, (1) The CP and its four maxims, (2) the GTVH and its six KRs. Linguists argue that both $\mathrm{CP}$ and GTVH are suitable for the analysis of a humorous text that requires hidden meanings to be conveyed (Grice 1975; Attardo, 2001).

The integration of these two frameworks in the study at hand is justified by their potentials to explicate the conversational, narrative, lexical and semantic features of the Facebook posts.

\section{ELLS Vol.9 No.I (218) SPU December 2018}


May Samir El Falaky

This occurs in the light of the socio-political and economic

\begin{tabular}{|c|c|}
\hline position & context \\
\hline 279 & خلينا نخلص بـتينخلصيل رب \\
\hline 544 & يا نُخلصن خلونا نشلص 7 \\
\hline 630 & النُخخلص بسر عة خلونـا نخلص 8 \\
\hline 2738 & ك يشتغرائخلصا نخلص بـتي 29 \\
\hline 2890 & 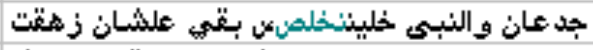 \\
\hline 7861 & 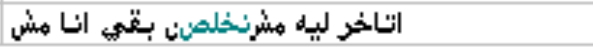 \\
\hline
\end{tabular}

Calculate

Figure (2) Textanz [Screen shot- concordance calculations]

scripts in the Egyptian society. Both, the KRs and the CP maxims are analyzed and the data are, then, displayed in such matrices, so that the following research questions can be answered:

RQ 1: In terms of GTVH, how is the Egyptian humor assembled to send the intended messages?

RQ 2: What socio-economic and political implications can be implied through Facebook discourse?

RQ 3: How can humor (de)construct public opinions?

\section{ANALYSIS}

The analysis of the data reveals that humorous Facebook posts are classified into four main themes as seen in Figure 3. The collected posts have a common target of criticizing the Egyptian Nuclear Program and ridiculing its commencement. Analyzing the posts thematically, the intended judgments are positioned to societal, economic and political affairs in Egypt. Figure (3) illustrates the percentage of themes in the whole corpus.

\section{$\begin{array}{llllll}\text { ELLS Vol.9 No.I } & \text { (219) SPU December } 2018\end{array}$}


The chart shows that the themes of the humorous posts

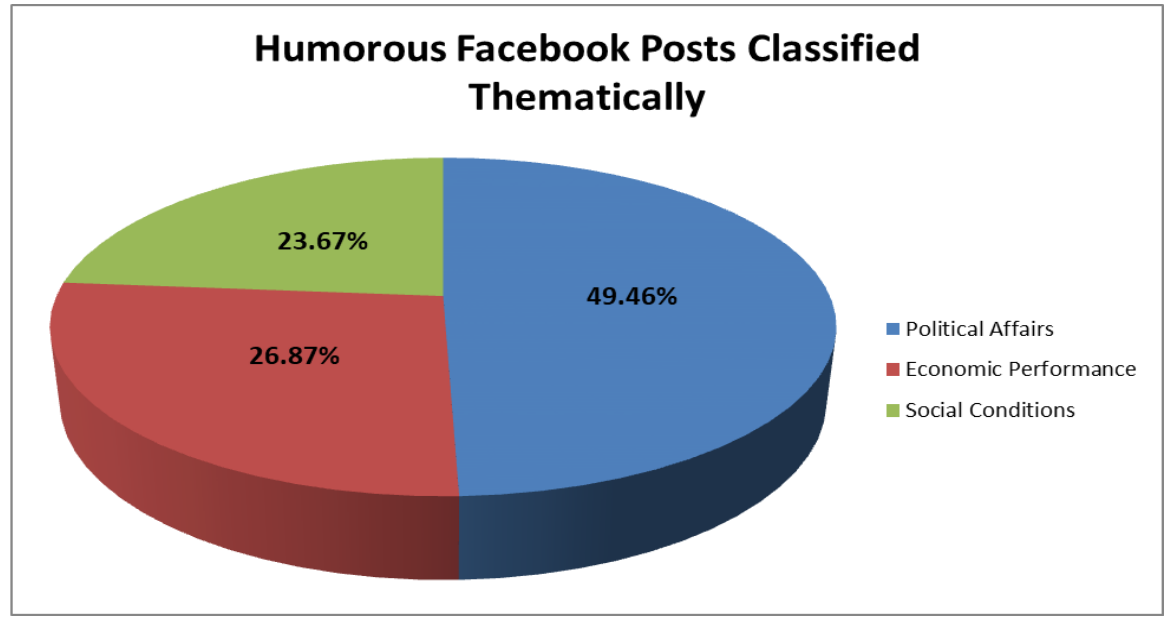

Figure (3) Humorous Facebook Posts by Theme

illustrate the possible thematic representations of the Nuclear Program in Egypt. Political disparagement is targeted with the major thematic reference with more than $49 \%$ of the total amount of the corpus. This theme determines how poltical issues, politicians and institutions are humorously rediculed.. Second in frequency is the humorous trend towards the economic performance.

A frequency of $26 \%$ tackles economic concerns, like major standards, national projects, etc. The analysis indicates that more than $23 \%$ are directed to societal issues, irresponsibilty and carelesness of the Egyptians. The examination of the posts revealed that these themes cover a number of topics comprising different features of verbal humor as will be seen in the followng divisions mirrored in actual examples from the corpus.

\subsection{Political Humor}

Political posts target national identity $(24.7 \%)$, institutional performance $(20.4 \%)$ and international relations $(4.3 \%)$. The

\section{ELLS Vol.9 No.I (220) SPU December 2018}


examples scrutinize the concept of national dissociation and evaluate the individual attachment to one's country (See Figure 4).

The politcal posts denigrate Egyptian politcal aspects such as

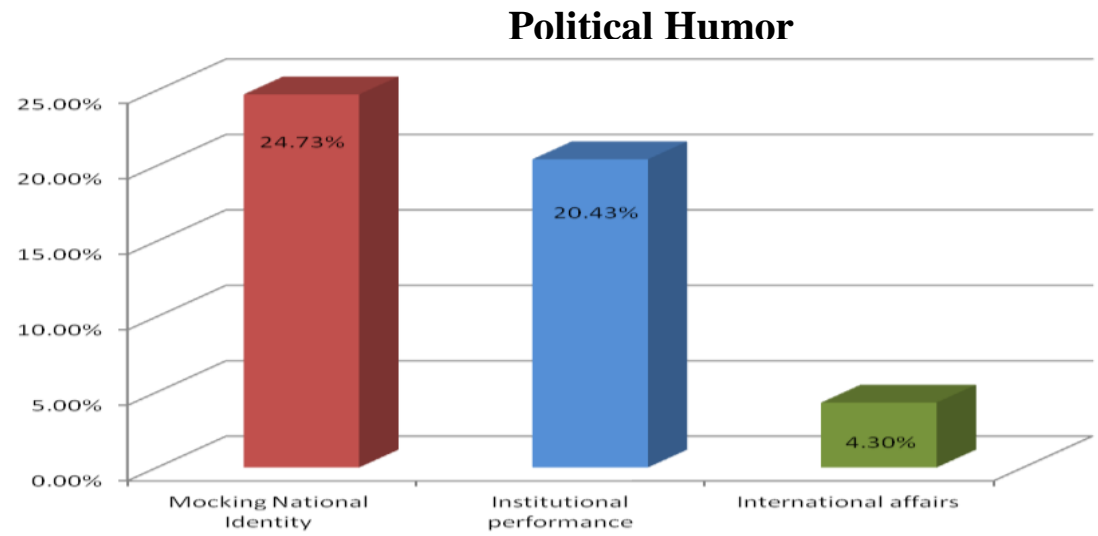

Figure (4) Political Humor

individuals, home-lands, attitudes, and behaviors.

Based on GTVH and CP, humor in the political theme is prompted by foregrounding the nuclear reactor as the target of the jokes. Politcial and national affairs are scorned in adajency with the idea of the commencement of the Nuclear Program in Egypt.

\subsubsection{Derision of National Identity}

The following instances show that Egyptians ridicule their national identity. The percentage is amounting to almost $24.7 \%$ of the total jokes. These posts are propped by expressing derision to the state of 'being Egyptian'.

In terms of GTVH, the jokes results from stereotyping the Egyptians and national identity as the source of failure and imprudence. All the jokes are triggered by relating two So together, one of which is the welfare resulting from the commencement of the Egyptian Nuclear Program (Positive/ good) and the other is scorning the Egyptian and the Arab identity (Negative/bad).

\section{ELLS Vol.9 No.I (221) SPU December 2018}


Serious Humor about the Egyptian Nuclear Program: A Pragmatic Analysis of Facebook Posts

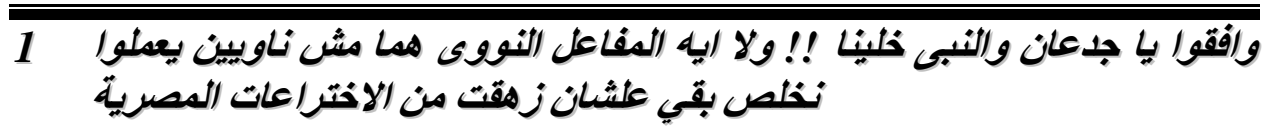

Aren't they going to operate the nuclear reactor or something!

Please agree, O fellows, for the Prophet's sake, let us get over with the Egyptian inventions.

SO Beneficial use of Nuclear power vs. the termination of the country

LM juxtaposition

TA Egyptian Nationality

SI Egyptian nuclear reactor is an instrument to destroy Egypt

NS Rhetorical question followed by $2^{\text {nd }}$ person narration

LA Reference, $1^{\text {st }}$ person pronouns (singular and plural) Jag line

CP: Implicature (maxim of manner, quality)

Example (1) shows that the writer is fed up with the inept Egyptian inventions. Calling for the termination of the country, the writer of the post is asking his peers با جدعان 'O, fellows' to announce their consents for the beginning of the nuclear plant as it is the only way to destruct Egypt; thus, a means of getting rest from these Egyptians misdeeds.

\section{كتبير كده \#..كفاية عرب لحد كده المفاعل النووى حد بشغل}

Let anyone operate the nuclear reactor; enough with the Arabs. It is too much.

SO Beneficial use of Nuclear power vs. the termination of the Arab countries

LM Exaggeration

TA Arab Identity

SI Egyptian nuclear reactor is an instrument to destroy the Arab world

NS Imperative

LA Reference, prep phrase showing extent

Punch-line

CP: implicature (maxim of relation and manner) 


\section{May Samir El Falaky}

In example (2), laughter is achieved by making a speech act of 'request'. Making requests is always beneficiary to the speaker. However, in this post, the writer is making a request for something that would harm oneself and the whole Arab nation. The punch-line ends the joke by exaggerating the challenging situation that the speaker has. The maxim of relation is broken; making the manner also unclear. For inferring the implicature, the reader has to presuppose that the Egyptian reactor would be incompetent.

\section{بشتثل وينفجر ...والليى انت الدفاعل النووى يا رب ....ما هو با الهجرة او 3

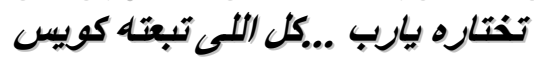

$O$, Lord, provide us either with a migration or let the nuclear reactor operate and explode ... And you choose it, Lord ...All are well and good.

SO Immigration vs. the commencement of the Egyptian

Nuclear Program

LM Analogy

TA Egyptian Nationality

SI Immigration or termination of Egypt are the same

NS Monologue

LA Reference, 2nd person pronouns, vocatives, register Jag line

$\mathrm{CP}$ : implicature maxim of quality, quantity

This post recalls the register of religion where the writer prays that he could either immigrate or that the nuclear reactor operates, thus his life could come to an end. The conjunction of يشتغل 'operates' and ينفجر 'explodes' shows that the negative consequences are not doubtful. The use of the vocative يا رب 'O Lord' twice, shows the writer's persistence that his life in Egypt would end. The statement is a monologue where the writer is using $2^{\text {nd }}$ person pronouns to create an atmosphere of soliloquy. The

ELLS Vol.9 No.I (223) SPU December 2018 
Serious Humor about the Egyptian Nuclear Program: A Pragmatic Analysis of Facebook Posts

maxim of quality is broken as the speaker here is asking for something he does not believe in, i.e. ending his life by death.

\section{علثان المفاعل النووى انا بقيت متوقع كل حاجة ف البلد دي بارب بقه بنجزو 4 نفرقع ونستربيح كلنا}

I can now expect anything in this country; $O$, Lord let them hurry up with the nuclear reactor so it explodes and we can all rest in peace.

SO Explosion vs. the commencement of the Egyptian Nuclear Program

LM Reasoning

TA Egyptian Nationality

SI Egyptian nuclear reactor explosion to get rid of Egypt

NS $1^{\text {st }}$ person narration

LA Vocative, cohesion, $1^{\text {st }}$ Reference (plural/ singular)

Punch-line

CP: implicature (quality maxim)

In example (4), an act of expectation is stated as an obvious fact where the 'cause' and the 'effect' are mentioned in the same sentence. The SO is clear in verbs يفرقع 'hurry up', يفزوا 'explode' and نستريح 'rest'. The verbalization of the humor is also clear in the exaggeration using words such as كل حاجه 'anything'

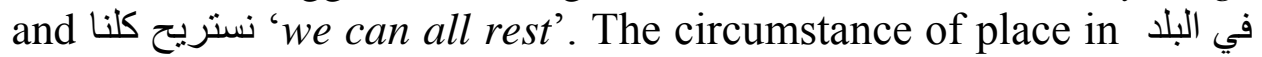

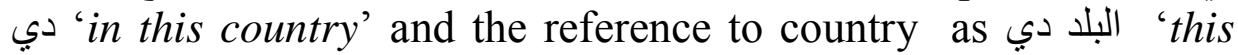
country' instead of using the proper noun 'Egypt' is deriding the country and belittling it. The use of indefinite label for Egypt is intended for distancing the writer from his home-land.

5

You would be stupid believing it is the end of the world unless

Egypt operates its nuclear reactor.

SO $\mid$ World end vs. commencement of he Egyptian Nuclear Program

LM Implied Consequence

ELLS Vol.9 No.I (224) SPU December 2018 


\begin{tabular}{l|l}
\hline \hline TA & Egyptian Nationality \\
SI & $\begin{array}{l}\text { Egyptian nuclear reactor is an } \\
\text { instrument to destroy the world }\end{array}$ \\
NS & $2^{\text {nd }}$ person narration \\
LA & $\begin{array}{l}\text { Reference, 2nd person pronouns } \\
\text { Jag line } \\
\text { CP: implicature (manner, relation } \\
\text { maxim) }\end{array}$
\end{tabular}

Example (5) triggers the scripts of the end of the world by the lexicalization of نهاية العالم 'the end of the world' and the script of operating the nuclear plant by the verb تعمل 'operates'. The SO is logically related by inferring to the consequence of the two actions. The attributing adjective غبي 'stupid' is used to modify anyone who opposes the belief borne in the post. The proposition is assertively stated in the second clause of the same post. These examples, among others, have an indirect implication of deriding Egypt and the Egyptian identity.

The language expresses a sense of alienation in the light of the contrast made by the commencement of the Nuclear Program and the desire of destructing their home-land. The humorous posts either end in jag lines as (1), (3), and (5) or in punch-lines as in (2) and (4). Interestingly, the posts utilized $1^{\text {st }}$ and $2^{\text {nd }}$ person narration to maintain relations with the reader and to claim in-group backgrounds. Examples (3) and (4) recall religious schemas of prayers which unlike real life, these posts pray for the destruction of their country.

\subsubsection{Institutional and Governmental Performance}

Examples (6-10) attack the government and its performance. Within the realm of this theme $(20.43 \%)$, facebookers intend to 'Target' the members of the government by expressing criticism and dissatisfaction of their institutional performance.

\section{ELLS Vol.9 No.I (225) SPU December 2018}


Serious Humor about the Egyptian Nuclear Program: A Pragmatic Analysis of Facebook Posts

سوهاج"... يا جماعه امتى "عمود كهرباء في منتصف الطريق الصحراوى قنا 6

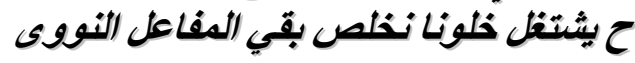

"An electricity pole in the middle of the desert road QenaSohag”... O' pals when will the nuclear reactor operate; let's get it over with.

SO Installing electricity pole vs. the operation of the nuclear reactor

LM Implied consequence

TA Nuclear power program

SI In Qena-Suhag Highway (regional )

NS $\quad 3^{\text {rd }}$ person narration followed by Rhetorical question

LA $1^{\text {st }}$ and $3^{\text {rd }}$ person, conditional clauses, vocatives, prepositional في منتصف phrase

Punch-line "خلونا نخلص"

$\mathrm{CP}$ : Implicature (Relation Maxim)

In example (6), the governmental mischievous installation of the electric pole in the middle of a highway road reflects its failure to achieve any progress. Typically, the semantic script of this post is identified in the lexamatic handles, عمود كهرباء 'electricity pole' (noun) and في منتصف الطريق الصحراوي 'in the middle of a desert road' (prepositional phrase). The second script, i.e. the operation of the nuclear reactor, presupposes its explosion. The implied consequence is only understood after reading the punch-line at the end. The punch-line asserts the deadly end of the Egyptian people who live contemporarily with the government that installs an electric pole in the middle of a highway road. Again, the SO activates implicature and is inferred by the shared knowledge between the writer and the reader.

\section{ELLS Vol.9 No.I (226) SPU December 2018}




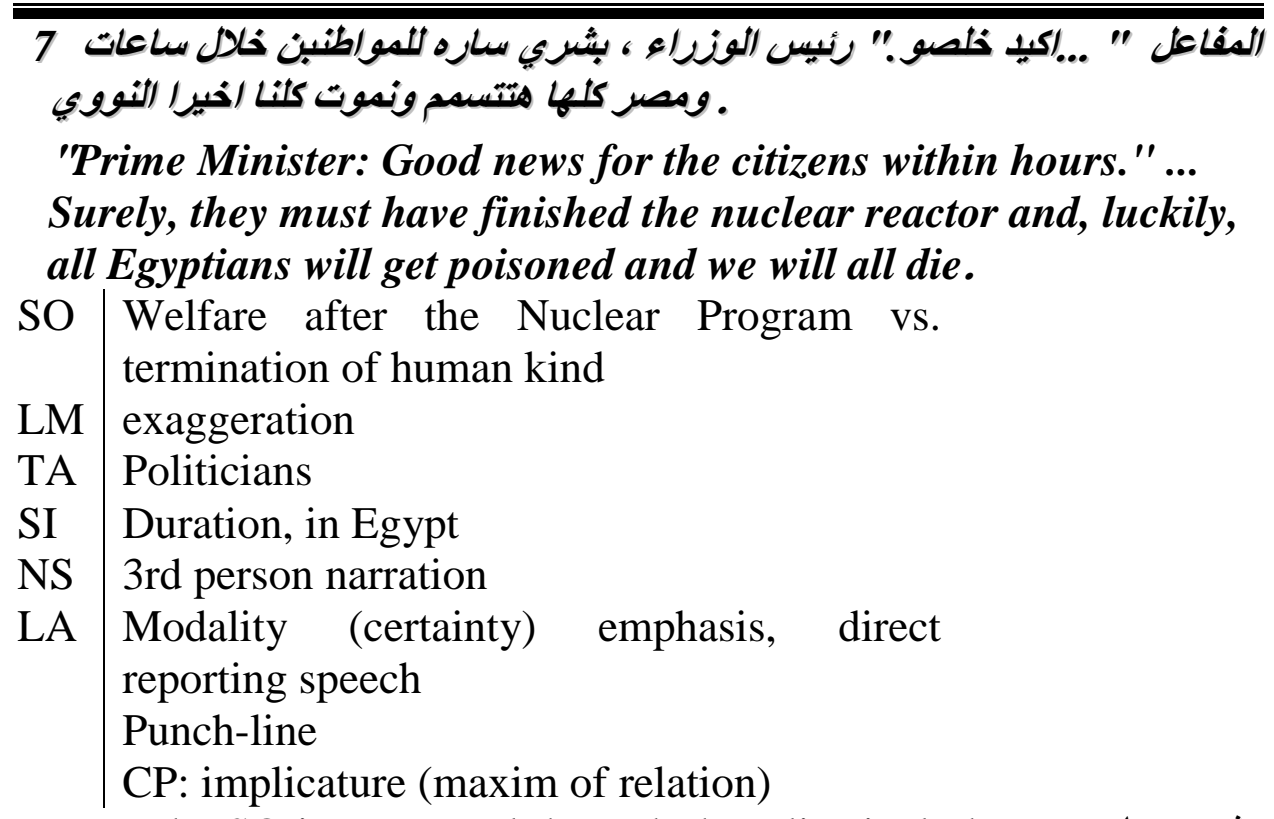

The SO is expressed through the adjectival phrase كشري ساره 'Good news' and the adverbial emphasis 'Surely'. These lexamatic handles highlight the implicature resulting from breaking the maxim of quality where the writer says something that is untrue. The writer intends to ridicule the officials whose announcements are not as pleasing as they announce. The sarcasm inferred through the verbalization of the consequences of operating the nuclear reactor, i.e., هنتسمم و نموت 'we will get poisoned and die'. Such verbs evoke impeded relevance between the two clauses. The use of the quotation recalls assertion of the intention of the government and this is asserted by the determination that all citizens are going to be poisoned and die.

ساعه مش عارفين يطفو حريق .امال لما المفاعل النووى بينفجر هنعل ايه It's been an hour and they still can't put out the fire. I wonder what they will do when the nuclear reactor explodes.

\begin{tabular}{l|l} 
SO & $\begin{array}{l}\text { extinguishing Nuclear reactor vs. } \\
\text { extinguishing little fire }\end{array}$ \\
LM Analogy &
\end{tabular}

ELLS VoI.9 No.I (227) SPU December 2018 


\begin{tabular}{l|l}
\hline \hline TA & Politicians \\
SI & Duration, time \\
NS & $\begin{array}{l}3^{\text {rd }} \text { person narration followed by a } \\
\text { rhetorical question }\end{array}$ \\
LA & $\begin{array}{l}\text { Reference, participant in } 1^{\text {st }} \text { person, } \\
\text { subordination, } \\
\text { Punch-line } \\
\text { CP: Implicature (Maxim of relation) }\end{array}$
\end{tabular}

This post scorns the people's suffering from the government's inability to extinguish little fire. The rhetorical question activates the script of the activation of the nuclear reactor. The SO is analogically presented in the question to accentuate the governmental failure to deal with critical situations. The broken maxim of relation does not hinder the understanding of the post. The background knowledge enables the reader to spot the severe criticism of the government. Interestingly, the zero conditional use of L 'when' asserts the implied consequence of the forthcoming nuclear reactor.

\section{9 فهل هتقدر تمنع .. إمتحانات أسئلة بعض تمنع تسريب بيقولك الحكومه مش قادره للإثشعاعات ؟ المفاعل النووى تسريب}

They say that the government is incapable of preventing the leakage of some exam questions.. So, can it, then, prevent the future leakage of the nuclear reactor radiations?

\begin{tabular}{l|l} 
SO & $\begin{array}{l}\text { Nuclear radiations leakage } \\
\text { vs. exam question leakage }\end{array}$ \\
LM & Analogy \\
TA & Statesmen \\
SI & Exam questions, leakage \\
NS & $3^{\text {rd person narration },}$ \\
LA & $\begin{array}{l}2^{\text {nd }} \text { perical question } \\
\text { homonymy metaphor }\end{array}$
\end{tabular}

ELLS Vol.9 No.I (228) SPU December 2018 
Jag line

$\mathrm{CP}$ : Implicature (Maxim of

relation)

Humor in example (9) results from the metaphoric nominalization of تسريب 'leakage' which is used once with اسئلة ' 'exam questions' and another time with nuclear radiations in the rhetorical question at the end of the text. Polysemy and the flouting the maxim of relation trigger the SO of exam question leakage and nuclear radiations leakage. Through this post, we can see that the writer is expressing his world view to the readers in which the government is incapable of securing minor issues; hence, it is incapable of maintaining a Nuclear Program.

إلى الفحم المفاعل النووي يشوي فنكوث الانقلاب \# يعد طول انتظر 10

After a long wait .. \# the coup has managed to barbeque the imaginary nuclear reactor!

SO Barbeque of beef or chicken vs. barbeque of

El-Fankush(unknown object)

LM False analogy

TA Egyptian Nuclear reactor

SI Long time awaiting, Egypt grills El-Fankush

(Unknown object)

NS $\quad 3^{\text {rd }}$ person narration

LA Metonymy, metaphor , reference , intertextuality

Jag line

CP: Implicature maxim of manner and quality

Humor in example (10) is emphasized by making reference to the cinema register. Background knowledge plays an important role in the interpretation of the implicature resulting from breaking the maxim of manner. Readers who laugh, understand that the word فنكوش pronounced as /fænku:f/ is quoted from one of the famous

\section{ELLS Vol.9 No.I (229) SPU December 2018}


Egyptian movies. The word does not have any meaning; it simply refers to an indefinable object that does not exist. The writer of this example projects the nuclear reactor as something illusive. The metaphoric reference of the BBQ of the 'El-Fankush' accuses the government propagating deceptive projects. The post reflects the political background of the writer as belonging to the opposition parties who reject the ruling of a president with military backgrounds. The word انقلاب 'coup' is a reference to the current ruling regime.

Throughout the previous examples, reference to the nuclear reactor triggers the script of welfare and prosperity. However, mentioning any achievement performed by the Egyptian government takes our line of thought to the failures of the government to achieve such promulgated welfare. These scripts are logically interrelated either by using implied consequence as in example (1), exaggeration as in example (2), analogy as in examples (3) and (4), or false analogy as in example (5). All examples flout the maxims of $\mathrm{CP}$ and stimulate the reader to search for hidden implications.

\subsubsection{International Affairs}

Egypt is a large country with outreaching international relations. The Nuclear Program has fostered the mutual relations with many countries, especially Russia which is the main sponsor for the program. The following instances reflect how Egyptians appraise such mutual relations in terms of comparisons drawn between the two countries.

\section{المفاعل النووى روسيا مش هترجع السياحه إلا لما تاخد حق 11}

Russia will not get Russian tourists back unless they get paid for the nuclear reactor.

\begin{tabular}{l|l} 
SO & $\begin{array}{l}\text { Honest business and } \\
\text { dishonest fraud }\end{array}$ \\
LM & Vicious circle \\
TA & Egyptian-Russian relations
\end{tabular}

\section{ELLS VoI.9 No.I (230) SPU December 2018}




\begin{tabular}{l|l}
\hline \hline SI & Tourism and power \\
NS & $3^{\text {rd }}$ person narration \\
LA & Antonyms \\
& Jag line \\
& CP: implicature maxim of \\
& quality
\end{tabular}

Example (11) depicts international relations between Egypt and Russia. Implicatures result in breaking the maxim of quality. In this post, the writer says something that is not real (flouting the maxim of quality). In reality, tourism was influenced by a terroristic attack aimed at Russian tourists visiting Egypt. The vicious circle of 'what comes first' is the mechanism utilized to link the two scripts of tourism income as well as the nuclear expenses. The lexamatic handles here are the two Arabic antonyms ترجع 'get back' and تاخد ' get paid. Again, the joke is aimed at the performance of the government, which failed, according to the post, to maintain both international affairs with Russia and the completion of the Nuclear Program in Egypt.

\section{"بوتن: لو حثث حرب بين روسيا و امريكا لن يبقى /حد على قيا الحياة" ... يا عم 12

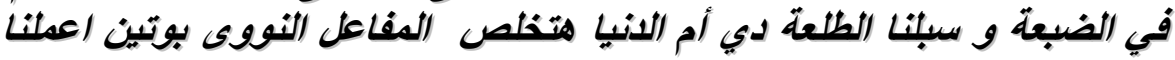 على كل عيألها}

"Putin: If war exploded between Russia and America, no one will

SO The commencement of the Nuclear Program vs. termination of the whole world

LM Exaggeration

TA Egyptian-Russian relations

SI War, ending life, nuclear reactor Dabaa,

NS Intertextuality

LA Reference, $1^{\text {st }}$ person, conditional clauses, vocatives, Punch-line

$\mathrm{CP}$ : Implicature (maxims of quality and quantity) not be alive" ... O' Mr. Putin, please establish the nuclear reactor 
in Dabaa, and Egypt (Mother of all nations) will terminate its entire citizens.

This post depends on a direct quotation reported by Putin, the president of Russia. Russia is an Egyptian ally and this is clear in the use of the informal vocative يا عم بوتن 'O Mr. Putin'. The punchline at the end of the joke explains the humorous effect of the joke. It triggers the script of the explosion of the nuclear reactor, which will probably end the human race, in analogy to the engendered total annihilation due to the destructive world war between Russia and the United States. The Russian-American war script, which is expressed through the conditional clause, is compatible with the manifestation of the destruction explicated in the punch-line that activates the SO. Through the reference ام الدنيا 'the mother of the whole world', the maxims of quantity and quality are broken and an ironic implicature is inferred about Egypt acclaiming that Egypt, the mother, will kill and end the lives of its people.

\subsection{Humor about Economic Performance}

The second main category of economy-focused humor relates the Nuclear Program to failure in different aspects, such as technical competencies, national projects and poor economic achievements.

The distribution of the ideas under this theme shows that the

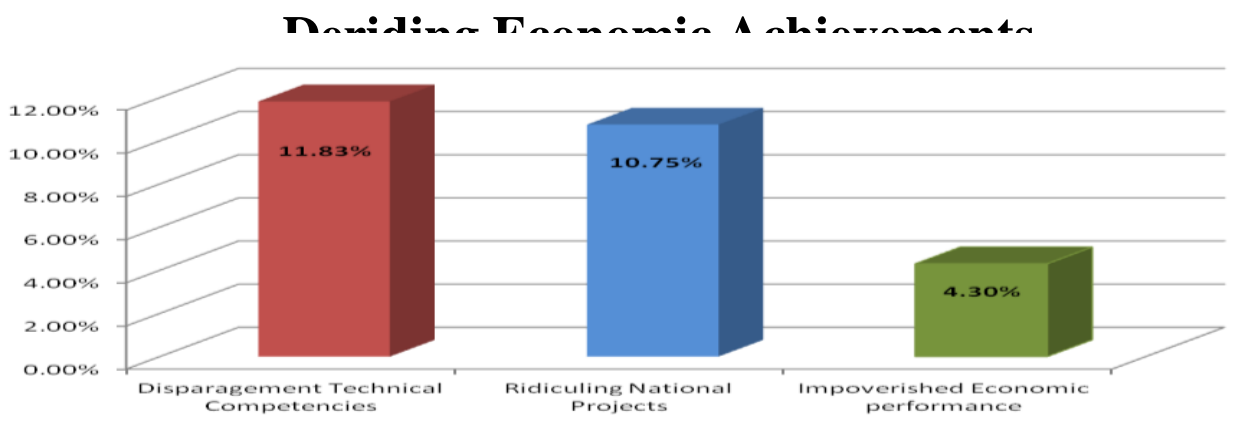

Figure (5) Deriding Economic Achievements

jokes scornsthe implied economic failure. In Figure (5), the

\section{ELLS VoI.9 No.I (232) SPU December 2018}


technical capabilities $(11.83 \%)$ are rediculed of their ineffectiveness to achieve their economic purposes. Similarly, both national projects $(10.75 \%)$ and the poor economic performance $(4.3 \%)$ resemble the Nuclear Program in its failure to improve the economic status of the Egyptians.

\subsubsection{Disparagement of Technical Capabilities}

The examples below, mirror people's opinions about the nuclear reactor which is regarded as a means of terminating and not enhancing the Egyptian's economic status.

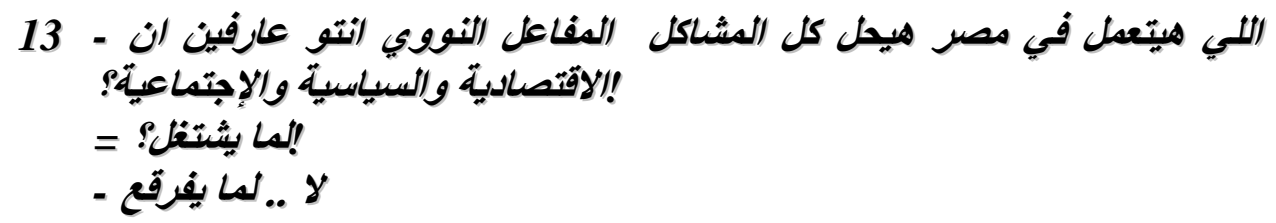

- Are you aware that the operation of the nuclear reactor in Egypt will solve all the economic, political and social problems?!

= When it works?!

- No, when it explodes.

SO Economic problems nuclear reactor

LM Faulty reasoning

TA Technical capability

SI Egypt, from nuclear power in Egypt

NS Dialogue questions/answers

LA Cohesion Punch-line

CP: no implicature

Example (13) utilizes the dialogic strategy in question/answer adjacency pairs. The writer intends to put down the Egyptian technical capabilities in terms of building and installing the nuclear reactor. The time reference $\omega$ ' when' and the $2^{\text {nd }}$ person 
pronominal reference انتو 'you' are intimate referential items used to reflect the intended idea. The punch-line at the end obviously breaks the maxim of quality as the writer intends to state something he claims to be true. The elements of the adjacency pair trigger the scripts of a challenging economic position in Egypt and that of the explosion of the nuclear reactor. The ridiculed target in this humor is the technical capabilities of the Egyptian engineers. Interestingly, the dialogue is prompted by complete adherence to the four maxims of CP. There are not any implicatures in the humorous texts. The punch-line affirms the inner belief of the writer and enunciates it, namely, the technical incompetence of the Egyptian nuclear reactor.

14

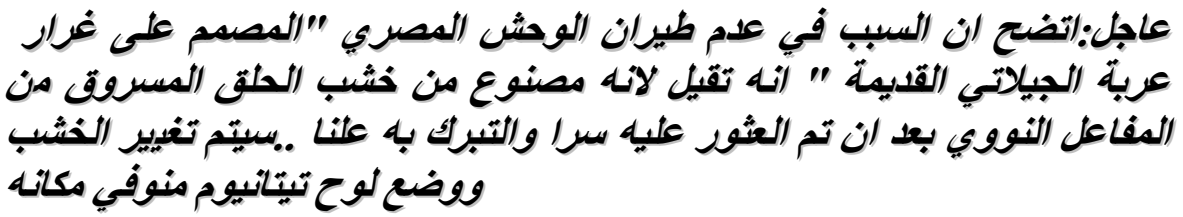

Breaking News: The reason why the Egyptian monster "designed like the classical ice-cream cart" has not been released is that it is made of wood stolen from the door post of the nuclear reactor after it was found secretly and publicly blessed.. but the wood will be replaced with Minufi titanium tablets.

SO High technicality of nuclear reactor vs. poor technicality of a wooden vehicle

LM False analogy

TA Technical capability of Egyptian projects

SI Nuclear reactor dissembled into wooden pieces to create a new vehicle

NS $\quad 3^{\text {rd }}$ person narration

LA Cohesion, background knowledge, register, extended metaphor Jag line

CP: implicature ( maxim of manner, quality)

\section{ELLS Vol.9 No.I (234) SPU December 2018}


Example (14) uses metaphor in الوحش المصري 'the Egyptian Monster' to refer to an Egyptian invented water-fueled vehicle. This metaphor is extended all through the example as the vehicle is composed of wooden components stolen from the 'sacred' establishment of the nuclear plant. The comparison is made in the simile على غرار عربة الجيلاتي القديمة 'like the classical ice-cream cart' where the water-fueled vehicle and ice-cream cart are similar in their attributes; the components are claimed to be derived from the nuclear reactor machinery (another metaphoric reference). The image of the 'sacred' nuclear reactor is depicted from the nominal use of التبرك به 'blessed'. The extension of the metaphor is stretched till the end of the joke with reference to a regional area Minufya (an Egyptian governorate) where most presidents descend from.

These figurative employment triggers the opposite scripts of the high technicality of the Egyptian inventions versus the poor technicalities of the wooden vehicle. The SO is interpreted by false analogy between a real object and an imaginary entity. The whole joke is based on flouting of the maxims of manner and quality. The speaker says something untrue which makes the message unclear and can only be inferred by shared background knowledge between the participants.

\subsubsection{Ridiculing National Projects}

After the critical period of the $25^{\text {th }}$ of January Revolution in 2011, the successive Egyptian presidents announce their concern about the economic conditions aiming at fostering the national projects for the sake of improving the economy and the resulting consequence of its decline after the massive unrest during the 2011 events. The following examples exemplify how the Egyptian people view such projects commenting on the feedback brought in.

\section{ELLS Vol.9 No.I (235) SPU December 2018}


Serious Humor about the Egyptian Nuclear Program: A Pragmatic Analysis of Facebook Posts

"صناعة الاقلام الرصاص و الاستبكه مههة " .... الله اكبرأ|خبرًا المشروعات 15

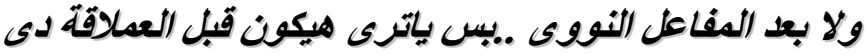

"Pencils and erasers industry is essential" ... Allah is Great, at last, mega projects in process.. But the important thing is, would be before or after the commencement of the nuclear reactor.

SO Small projects versus national projects

LM False analogy

TA National projects

SI Egypt time before or after building the nuclear reactor

NS Narration followed by a rhetorical question

LA Reporting speech, cohesion

Jag line

$\mathrm{CP}$ : implicature ( maxim of relation, quality)

In example (15), using quotations supports the proposition stated in the joke. Being a factual statement, the first script is triggered about the nature of small projects. The true/false SO lies in the quality-broken maxim اله اكبر اخيرا المشروعات العملاقة 'Allah is Great, at last, mega projects in process' where the speaker is saying something he does not believe to be true. The punch-line that comes at the end in the form of a question reflects irony and creates a false analogy between little and national grand projects. The cohesivelylinked question implies that after the installation of the nuclear reactor, Egyptian people would not need any more projects as they would be terminated.

\subsubsection{Impoverished Economic Performance}

The Egyptian people have long accused the successive governments of their poor economic performance. Despite their various declarations and announcements, those Egyptian governments failed to make people get a concrete feedback of their efforts on the economic perspective. The following examples describe how the Egyptian people evaluate the economic status as impoverished.

ELLS Vol.9 No.I (236) SPU December 2018 
"ا ا الف جنبه قبيةة فاتورة كهرياء شقه بالدقهلية في شهر واحد" ... نسى بطفى 16

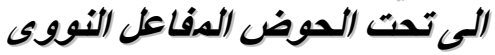

"51 thousand pounds is the value of one-month electricity bill in an apartment in Dakahlia." He might have forgotten the nuclear reactor under the basin switched on.

\begin{tabular}{l|l} 
SO & $\begin{array}{l}\text { Power consumption of the } \\
\text { nuclear reactor vs. power } \\
\text { consumption in small houses }\end{array}$ \\
LM & False analogy \\
TA & Economic status \\
SI & Governorate small house \\
NS & Third person narration, \\
LA & $3^{\text {rd }}$ person pronoun, reporting \\
& speech \\
& Punch-line \\
CP: implicature ( maxim of \\
relation, quality)
\end{tabular}

This humorous text is only interpreted after the punch-line is stated. The punch-line reveals the script of power consumption made by the nuclear reactor which is the only cause for the overpaid electricity bill that reached 51 thousand pounds. The second script of the expensive electricity bills is triggered by the direct quote taken from a news report. Both the reporting speech and the $3^{\text {rd }}$ person narrative punch-line help in interpreting the irrelevance caused by the implicature intended in the post. The economic status of the Egyptians has long been the focal point of critical discourse and in this post it is the target of this humorous text. The prepositional phrase تحت الحوض 'under the basin' prompts laughter because of the location of the presumed nuclear reactor, which is referred to as the only justification for the exorbitant electricity bill.

\section{ELLS Vol.9 No.I (237) SPU December 2018}


Serious Humor about the Egyptian Nuclear Program: A Pragmatic Analysis of Facebook Posts

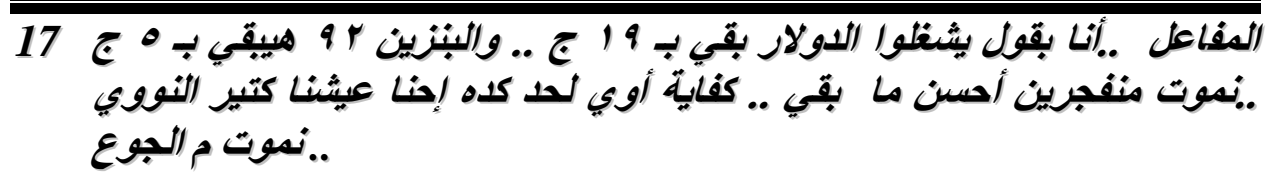

The dollar rate has become $19 \mathrm{LE}$.. and petrol price will be $5 \mathrm{LE} /$ liter.. I suggest that the nuclear reactor should get operated.. We had enough; We lived a lot so far; Let's better die exploded than starved..

\begin{tabular}{l|l} 
SO & Welfare after Operating \\
& $\begin{array}{l}\text { nuclear reactor vs. poor } \\
\text { economic status }\end{array}$ \\
LM & Exaggeration \\
TA & Economic status \\
SI & Egypt, currency, prices \\
NS & $3^{\text {rd }}$ and $1^{\text {st }}$ person narration \\
LA & Collocations and repetition \\
& $1^{\text {st }}$ person pronouns \\
& Jag line
\end{tabular}

$\mathrm{CP}$ : implicature (maxim of relation, quality, quantity)

The writer of example (17) is lamenting over the over-rated dollar prices and the expensive price of the gasoline and benzene. This example comprises words collocating with the economy register. The second half of the joke evokes the image of launching the nuclear reactor. Exaggeration in the shared suffering is clear in the lexamatic handles such as كفاية 'enough', كتير 'a lot'. In-group identity is claimed in the $1^{\text {st }}$ person plural pronoun احنّ 'we' and the bound pronoun نـ نموت ine die'. The punch-line elucidates the reason behind the previous statement that is to die with explosion is better than death of starvation. So, the nuclear power is an instrument of death and not welfare as claimed in the opposite scripts.

\section{ELLS Vol.9 No.I (238) SPU December 2018}




\section{May Samir El Falaky}

\subsection{Societal Conditions as Humor Target}

Examples uder this theme address the societal conditions of the Egyptian people. Interestingly, the major humorous posts are criticizing the 'self'. People's ignorance and carelesness (10.76\%) are disapproved and negatively evaluated. Females, geography and traditions are also ridiculed by assimilating their attitudes with the Nuclear Program. The least frequently humorous posts, despite its significance, is the bureaucracy and ted tape. Jokes under this theme is utilized in comparison with a crucial program such as nuclear and atomic fields.

\section{Mocking Societal Conditions}

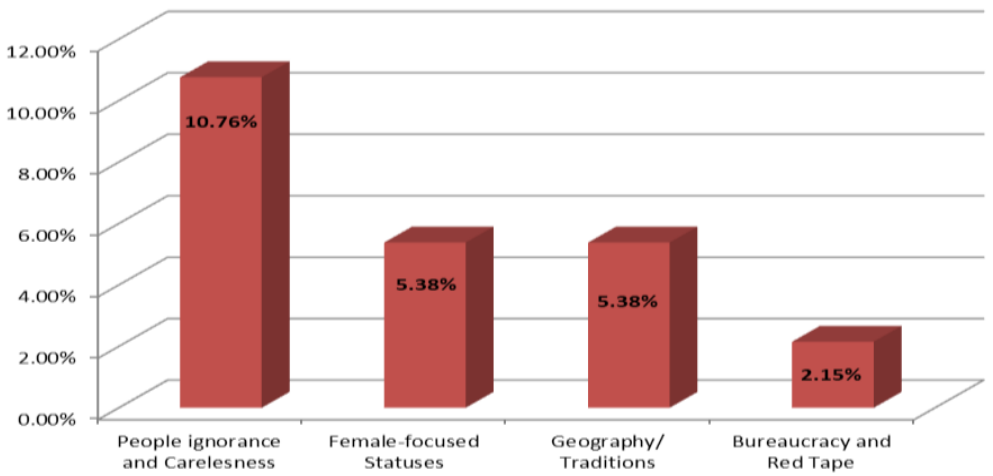

Figure (6) Mocking Societal Conditions

The following examples demonstrate how facebookers evaluate the surrounding societal conditions by criticisng the self and the other, criticising geography and unaccepted traditions. The examples pinpoints how social media can be regarded as a measure to the degree of acceptance and rejection of the societal norms in Egypt. 


\subsubsection{People Ignorance and Carelessness}

Egyptian people always criticize themselves and the other. Humorous texts and jokes are not always other-attacking mechanisms. The following examples show how humor can be targeted to attack groups, individuals, attitudes and behaviors.

\section{لوحده المفاعل على عربية فول : شقتين فول بسرعه يا عم حماده علشان سايب 18}

On a bean-serving cart: two halves of bean sandwiches please.

Hurry up, Hammadh, because the reactor remains unattended

SO Having breakfast vs. critical job

LM Implied Consequence

TA Egyptian employees

SI On beans-serving cartemployee

NS Dialogue

LA Ellipsis, subordinating conjunction, vocative

Jag line

$\mathrm{CP}$ : implicature ( maxim of quality)

Humor in example (18) seeks to criticize carelessness of the Egyptian people. The scenic circumstance is described 'on a beanserving cart'; there, an employee is working in a critical job, in a nuclear reactor, asking the waiter to quickly serve him because his place is left unattended. Of course, this is an imaginary situation breaking the maxim of quality but the analogy with the carelessness of the Egyptian employees generates an image of irresponsibility. The subordinating conjunction عشان 'because' enunciates the reason for the haste. In our minds as readers, the rush triggers laughter because such critical task requires more responsibility than that expressed in the post. The text elided the word النووي and the

\section{ELLS VoI.9 No.I (240) SPU December 2018}




\section{May Samir El Falaky}

عم مفاعل 'reactor' is only mentioned to show intimacy with . 'Hammadh' the vocative.

سائق إسعاف بالمنصورة بيتوقف بمريض بتألم لشراء فطبر..المفاعل النووى 19 بسرعة خلونا نظلص النوص

An ambulance driver in Mansoura stops with a suffering patient on board to buy a pie. Let the nuclear reactor be quickly launched.

\begin{tabular}{l|l} 
SO & $\begin{array}{l}\text { Having breakfast vs. critical } \\
\text { job }\end{array}$ \\
LM & Implied Consequence \\
TA & Egyptian employees \\
SI & Participant, in El Mansura \\
NS & $3^{\text {rd }}$ person narration \\
LA & $3^{\text {rd }}$ person pronoun $1^{\text {st }}$ person \\
& pronouns \\
& Punch-line \\
& CP: implicature ( maxim of \\
& relation)
\end{tabular}

Similar to example (18), the writer in joke (19) intends to ridicule the Egyptian carelessness. A critical worker such as an ambulance man leaves a suffering patient to buy a pie. The post includes two scripts, buying food and rushing in with a patient by the ambulance. The punch-line at the end shows the writer's desire of the commencement of the nuclear reactor. Despite breaking the maxim of relation, readers are capable of interpreting the implicature as it recalls the script of the termination of the world. The implied consequence is that all people's lives would come to an end.

\subsubsection{Female-focused Humor}

Female-focused jokes show that the employees who are responsible for the destruction of the world are females مدام عنايات 'Madam Annayat' as in example (20) or مدام عفاف 'Madam Afaf' as

ELLS Vol.9 No.I (241) SPU December 2018 
in example (21). Such depiction stereotypes married females as the reason of crises. The following example asserts the stereotyping of females as irresponsible careless objects.

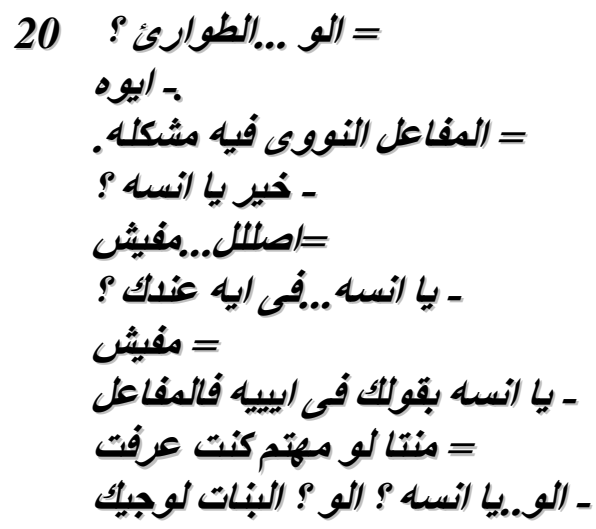

=Hello, Emergency ...?

-Yes .

$=$ The nuclear reactor has a problem.

- Well, what is it, ma'am?

= In fact ... nothing!

- Ma'am ... What is it?

= Nothing

- Ma'am what is wrong with the reactor?

= Nothing, if interested you would have known alone

- O' ma'am? What?

Girls' Logic

\begin{tabular}{l|lr} 
SO & \multicolumn{2}{|l}{ Female-male romantic talk } \\
vs. critical situation & \\
LM & Analogy & \\
TA & $\begin{array}{l}\text { Feminine attitudes with } \\
\text { males }\end{array}$ \\
SI & $\begin{array}{l}\text { Female } \\
\text { telephone call } \\
\text { NS }\end{array}$ & Dialogue
\end{tabular}

\section{ELLS Vol.9 No.I (242) SPU December 2018}




\begin{tabular}{l|l}
\hline \hline LA & Adjacency pairs \\
& jag line \\
& $\mathrm{CP}$ : implicature (maxim of \\
& relation, quality, quantity)
\end{tabular}

Example (20) is an analogy assimilating the female-male romantic talk with an emergency telephone call, which is concerned with nuclear-related crisis. The policeman is trying to know what the problem is and the female (unmarried) keeps on playing hard till the jag line ends it all with مانت لو مهتم كنت عرفت 'if interested you would have known'. Such analogy reflects female attitude with males, who claim that they don't understand females and their needs. The vocative represented in يا انسه 'O' ${ }^{\prime}$ ' ${ }^{\prime}$ 'am' is reiterated by the policeman, so as to presume the problem she is calling for. The whole scene triggers the two incongruent scripts of romantic talk versus nuclear-related danger. Phonologically, the stress in the /// sound in لصلس 'In fact' shows that the female is rethinking about whether to tell the policeman about the problem or not. Similarly, the stress on the /i:/ sound in في ايييه؟ 'what's wrong?' connotes the insistence of the policeman to know the problem for the sake of resolving the issue. Societal elements are recalled here and the joke is only interpreted by the shared background knowledge between the speaker and his in-group intimates.

\subsubsection{Geography \& Traditions}

Egyptian geographic location with its outreaching governorates and its deeply rooted heritage of traditions are the fusion that creates the Egyptian identity. Humor targeted to these structures can be seen in the following examples.

\section{يا رب المفاعل النووي بتبنى فى المنوفيه}

\section{$O$ Lord, Let the nuclear reactor be established in EL Minufia}

SO Welfare after operating the nuclear reactor vs. explosion of the nuclear reactor 
LM Implied consequence

TA Minufi people/presidents

SI Egyptian governorate,

NS Monologue

LA Religious words, reference metonymy

Jag line

$\mathrm{CP}$ : implicature ( maxim of quality, manner)

Example (21) brings in the religious context where someone is praying for the good of the beneficiary. The humorous effect in this post is triggered due to the implicature achieved by breaking the maxim of quality. The writer states something he believes to be untrue. The writer assumes and presupposes that the nuclear reactor is going to be exploded (first script). As background knowledge, we all know that previous Egyptian presidents are Minufy people (from the governorate of Minufeya); the opposing script is triggered and the prayers of the construction of the nuclear plant in this particular governorate is intended to destruct this particular governorate. The humor in this post deviates from the usual form of clear obvious jokes. It is based on shared background knowledge through which the interpretation is made successful.

\section{ماشي فل الدفاعل النووي إنفجار محول كهريا في جامعة جنوب الوادي بقنا.بس 22 الفل}

An explosion in an electric hub in South of the Valley university, but the nuclear reactor is properly operating.

SO Explosion in electricity field vs. nuclear reactor operation

LM False analogy

TA Nuclear reactor

SI Regional area governorate electricity hub

NS $\quad 3^{\text {rd }}$ person Narration

LA Cohesion nominalization, slang

Jag line

$\mathrm{CP}$ : implicature ( maxim of quality, relation)

\section{ELLS VoI.9 No.I (244) SPU December 2018}




\section{May Samir El Falaky}

The post relies on a factual statement quoted from a news report about the explosion of an electricity hub in a university in Upper Egypt. This is represented by the nominal انفجار 'explosion', where the reason is not identified. In the punch-line of the joke, the writer broke the maxim of quality. He says something that is not true about the well-functioning of the nuclear power despite this accident. This well-functioning is clear in the use of the slang فل الفل 'good as flower'. The implicature resulting from the flouting of the maxim of relation activates the scripts of proper functioning of the nuclear plant and the explosion of the electricity hub. Such analogical opposition shows how real and unreal conditions contradict with each other. The post is a means of criticism to the performance of the government.

\section{دلوقت التجمع بلون مياة وبدون غاز لان حفار شركة المياة هو اللي فجر خط الغاز 23 ها بخلص امتى ج؟؟ المفاعل النووي قلتلي هان.فقفلوا الاتنين ):}

Now the $5^{\text {th }}$ settlement is without water and gas because the water company digger blew up the gas line. you were asking when the nuclear reactor will operate.

\begin{tabular}{l|l} 
SO & $\begin{array}{l}\text { Operation of the nuclear } \\
\text { reactor vs. bad conditions }\end{array}$ \\
LM & Juxtaposition \\
TA & Societal conditions \\
SI & $\begin{array}{l}\text { Rich suburb time (now) } \\
\text { instrument without cause }\end{array}$ \\
NS & $\begin{array}{l}\text { Narration followed by } \\
\text { rhetorical question }\end{array}$ \\
LA & $\begin{array}{l}\text { Cohesion } \\
\text { Punch-line } \\
\text { CP: implicature (maxim of } \\
\text { manner, relation) }\end{array}$
\end{tabular}

Unlike example (22), this example shows poor utility services in a superb area which is supposed to be a prosperous region. The 
implication here shows that even rich geographical areas suffer from the poor social conditions and this is clear through the cohesive device 'لأنbause'. The punch-line breaks the maxims of relation where the citation of the nuclear reactor is out of context. The juxtaposition of the two scripts of operating the nuclear plant and lack of utilities in the superb area creates unclear implications. Of course, background knowledge is utilized to assume the hidden relations between the elements of the post. The nuclear reactor is assumed to explode and terminate all Egyptians; hence human race will be relieved from the societal services in Egypt. The narration is employed to give the sense of factual statement and the rhetorical question is stated to show how desperate the Egyptian people feel to end their sufferings from the societal conditions.

$$
\text { الفسيخ قبل رمضان والعبي.. دمالار شامل ) المفاعل النووي (مساء الخيز .. } 24
$$

Good evening.. the salted fish (Nuclear reactor) comes before

Ramadan and Eid .. Mass destruction

SO The tradition of eating Salted

fish vs. mass destruction

LM Analogy

TA Traditions salted fish

SI Eating salted fish before the

fasting month

NS $\quad 3^{\text {rd }}$ person narration

LA $3^{\text {rd }}$ person pronoun,

metaphor, collocation,

orthographic deviation

Punch-line

CP: implicature ( maxim of manner, relation)

Humor in example (24) is stimulated from the metaphoric reference to the tradition of eating salted fish. The writer assumes correspondence between salted fish and mass destruction. Criticizing this tradition is assumed by the time of eating this food,

\section{ELLS Vol.9 No.I (246) SPU December 2018}


namely, before Ramadan a religious month where Muslims fast and avoid drinking and eating from sunrise till sunset. The orthographic deviation in the punch-line دماll 'destruction' creates a phonological atmosphere, as if the writer is shouting using the vowel /a:/. It is the knowledge of the contexts of situation and culture that enables recipients to arrive at the interpretation and induce the implicature intended by violating the two maxims of relation and manner. The resemblance of the salted fish with the nuclear reactor is what triggers laughter in this joke.

\section{المفاعل النووي على العريب و لا العروسة 25}

\section{Who is going to buy the nuclear reactor, the bride or the groom?}

SO $\mid$ Dowry tradition expenses nuclear reactor expenses

LM Analogy

TA Traditions of marriage

SI Participants beneficiaries

NS Question

LA Substitution, intertextuality Jag line $\mathrm{CP}$ : implicature ( maxim of manner)

In example (25), the two scripts of the expenses of dowry tradition and the expenses of building a nuclear reactor are intertwined by shedding light on the resemblance between them. Due to the huge expenses of both the laughter is activated. "Who is supposed to pay such expenses, the bride or the groom?" is a question posed in the rhetorical question and is kept unanswered. The implicature is made unclear unless the reader assumes shared knowledge in the post. This post is a parody to the famous question that assigns the dowry and furnishing the house on the bride or the groom. The word المفاعل النووي 'nuclear reactor' is substituted with a furniture piece. 


\subsubsection{Deformed Bureaucratic Procedures}

The reader of Facebook humorous posts can easily construe a classical analogy with bureaucratic procedures and red tape. Finishing official papers and documents in governmental institutions is a frustrating activity. People have to go through numerous procedures before finishing an intended document. The following examples criticize and mock such deformed official procedures in an inquiry about how the Nuclear Program would proceed within such lame processes.

\section{بسرعة shutdown عالبة جذا ولازم يتعمله المفاعل النووى المهنس :حرارة 26

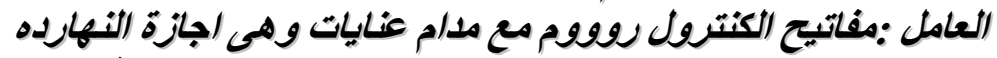 مشهب مختصر لنهاية العالم النهارد}

The Engineer: The heat of the nuclear reactor is very high and needs to be shut down quickly

Worker: The keys of the control room are with Madame Annayat, and she is on vacation today

A brief view of the end of the world

\begin{tabular}{l|ll} 
SO & crisis vs. bureaucratic \\
LM & procedures & \\
TA & Exaggeration & Red tape \\
SI & Governmental institutions in \\
NS & Egypt & Dialogue \\
LA & Collocation of office work, \\
& $\begin{array}{ll}\text { register } \\
\text { deviation } \\
\text { Punch-line } \\
\text { CP: implicature ( maxim of } \\
\text { manner, quality) }\end{array}$
\end{tabular}

The dialogue-formatted humor in example (26) evokes two scripts the bureaucratic and the crisis of the end of the world. A sum of pragmatic and semantic features creates the humorous effect in

\section{ELLS VoI.9 No.I (248) SPU December 2018}




\section{May Samir El Falaky}

this joke. The collocation of Egyptian governmental office work can be exemplified in مدام عنايات 'Madam Annayat'. The typical name of an employee, who is famous of red tape, and her sate of being on a vacation و هي اجازة النهارده both leave the reader with a state of mind to imagine what would be the situation if the temperature of the nuclear reactor increases and only Madam Annayat has the resolution to this crisis. It is the exaggeration in linking the two scripts and the official register that decode the implicature resulting from breaking the maxims of manner and quality. The phonological features are clear in the orthographic deviation in stressing the sound /u:/ in روووم 'room' to convey the meaning of shouting due to the crisis explicated in the post. The punch-line summarizes the whole situation as it is the scenery of the termination of the world

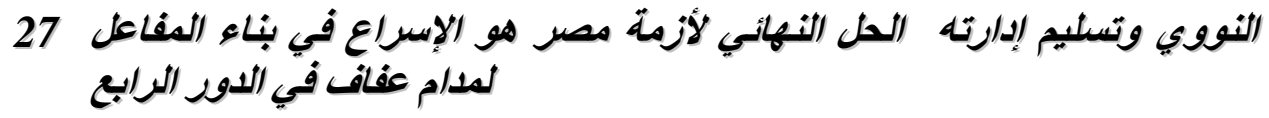

The final solution to the crisis in Egypt is to accelerate the construction of the nuclear reactor and hand over its management to Mrs. Afaf in the fourth floor

SO $\mid \begin{aligned} & \text { Destruction vs. bureaucratic } \\ & \text { procedures }\end{aligned}$

LM Implied consequence

TA Red tape

SI Governmental institution in Egypt

NS 3person narration

LA Collocation of office work, Jag line

$\mathrm{CP}$ : implicature ( maxim of manner, quality)

Example (27) emphasizes the concept inferred in example (26) but in a form of $3^{\text {rd }}$ person narration. Again red tape and deformed bureaucratic procedures are being ridiculed by triggering the opposite script of the nuclear reactor destruction. The implied

$\begin{array}{llllll}\text { ELLS VoI.9 No.I } & \text { (249) SPU December } 2018\end{array}$ 
consequence is the termination of Egypt, thus all the problems would come to an end. Reiteratively, the head words (nominal) تسليم 'hand over', (noun) ادارة 'management' and the prepositional phrase 'in the fourth floor' collocate with the register of governmental institutions. Like example (26), the implication is inferred by making assumptions of the shared background knowledge about official institutions in Egypt.

\section{CONCLUSION}

The analysis of the Egyptian humorous texts demonstrates that such discursive practice primarily serves three functions, (1) criticizing, (2) raising awareness and (3) acclaiming in-group identity. The study has sought to disassemble the verbalizations of humorous texts to stand for the linguistic features responsible for the formation of such linguistic phenomenon.

Answering RQ 1, the study has found that Egyptian humor relies significantly on script opposition especially when imposing unreal scripts on the real accepted ones. While the script of the commencement of the Nuclear Program presupposes welfare on the political and socioeconomic reality, these specific aspects are scornfully mocked using nuclear referents as targets for the Egyptian jokes. Despite the existence of the KRs in the texts, the Egyptian tendency to compare the nuclear power with all aspects of life triggers the humorous effect resulting from judging the current situations in Egypt.

This takes us to the proposition made by Attardo and Raskin (1991) about the hierarchical nature of the KRs SO, LM, SI, TA, NS, and LA. Still, the study shows that the TA is the parameter that controls how the humor proceeds. The nuclear reactor is the chief variable that all disputes are compared with. The study shows that the Egyptian humor can presume an entity, stereotype it, and then considers it a target that every other derided element can be compared with.

In other words, In terms of GTVH, SO is the KR that demonstrates the contrasts in the joke, however, win standardizing

\section{ELLS Vol.9 No.I (250) SPU December 2018}




\section{May Samir EI Falaky}

one of the scripts (Nuclear Program) through all jokes, they still achieve their humorous effect.

RQ2 is answered through focusing on the verbal features of the Egyptian humor and the implication resulting from such verbalization. The verbalization of the Egyptian humor in digital discourse explicates the socio-economic and ideological implications lurking within such discourses. Egyptian humor is aspired by the contexts of situation and culture aiming at maintaining solidarity and in-groups identities. The construal of Egyptian humor requires a profound understanding of the socioeconomic and political information surrounding the discourse.

Thus, all humorous texts are loaded and constituted by ideologies. The analysis of humorous posts demonstrates how the writer seeks to construct the 'US' (Egyptian citizens, poor people) and deconstruct 'THEM' (government, rulers). This hands-off attitude is clear in the humorous posts that intend to depict the increase of the social distance between the people and the governmental institutions in Egypt. The understanding of the humorous texts requires the inclusion of extra information and cannot be maintained without cultural assumptions, so it can be judged that the linguistic selections in the humorous texts can be by no means unintentional.

Facebook humorous discourse is an influential medium that shapes and is shaped by the public opinion. RQ3 is answered by analyzing the linguistic features that are intended to communicate existing opinions, attitudes and judgments towards the Nuclear Program in Egypt. In terms of socio-political shared knowledge, background, scripts and schema readers can witness how the posts delegitimize the construction of the project. The results explain the reasons why such sector of the Egyptian population disagrees on the project. Facebook content is strongly influenced by how Egypt's Nuclear Program is positioned in the Egyptian society.

\section{ELLS Vol.9 No.I (251) SPU December 2018}


The analysis reveals that the ideological stance of Facebook users contradicts that of the state legitimizing the Egyptian reluctance regarding the nuclear power in Egypt. The results, also, show how Facebookers pursue the delegitimization of the the political institutions that intend to proceed with the highly propagated Nuclear Program. 


\section{REFERENCES}

Aguza, L. (2017). Narrative Strategy As Humoristic Resource In Sitcom: The Case Of How I Met Your Mother. Estudios De LinguisticaUniversidad Dealicante-Elua, 31, 9-25. DOI: 10.14198/ELUA2017.31.01

Attardo, S, \& Raskin, V. (1991). Script Theory Revis(it)ed: Joke Similarity and Joke Representation Model. Humor: The International Journal of Humor Research, 4 (3-4),293-348.

Attardo, S. (1994). Linguistic Theories of Humor. Berlin: Mouton de Gruyter.

Attardo, S. (2001). Humorous texts: A semantic and pragmatic analysis. Berlin: Mouton de Gruyter.

Attardo, S. \& Hempelmann, C. \& Di Maio, S. (2002). Script oppositions and logical mechanisms: Modeling incongruities and their resolutions. Humor-international Journal of Humor Research HUMOR. 15. 3-46. 10.1515/humor

Bergson, H. (1911). Laughter. New York: Macmillan.

Canestrari C, Branchini E, Bianchi I, Savardi U, Burro R. (2017). Pleasures of the Mind: What Makes Jokes and Insight Problems Enjoyable. Front-Psychol 8(1), 2297.

Egyptian Atomic Energy Authority. (n.d.). Historical Background. Retrieved from http://www.eaea.org.eg/aboutus.html

Grice, P (1975). Logic and Conversation. In Cole, P., and Morgan, J. Speech Acts. Pp. 41-58. USA: Academia Press.

Grice, P. (1989). Studies in the way of words. Cambridge: Harvard Uiversity Press.

\section{ELLS Vol.9 No.I (253) SPU December 2018}


Serious Humor about the Egyptian Nuclear Program: A Pragmatic Analysis of Facebook Posts

Heidari-Shahreza, M. (2017). A Sociolinguistic Analysis of Gender in Persian Verbal Humor: The Case of Online Jokes.Gender Issues. https://doi.org/10.1007/s12147-017-9206-9

Karpinska-Krakowiak, M. \& Modlinski, A. (2018) Popularity of Branded Content in Social Media, Journal of Computer Information Systems, DOI: 10.1080/08874417.2018.1483212

Kellner, C. (2017). Factors affecting irony alignment in an online message board (Doctoral dissertation). Retrieved from ProQuest Dissertations \& Theses Global. (2017195633)

Minsky, M. (1980). Jokes and the Logic of the Cognitive Unconscious. In HINTIKKA, J. (ed), Cognitive Constraints on Communication: Representation sand Processes. Reidel: Dordrecht.

Monro, D. (1951). Argument of laughter. Melbourne: Carlton University Press.

Morreal, J. (1987). The Philosophy of Laughter and Humor. Albany: SUNY.

Morreal, J. (1989). Enjoying incongruity. Humor 2 (1), 1-18. DOI: https://doi.org/10.1515/humr.1989.2.1.1

Pickering B., Thompson, B. \& Filik, R. (2018). Examining the emotional impact of sarcasm using a virtual environment, Metaphor and Symbol, 33:3,185-197, DOI: 10.1080/10926488.2018.1481261

Raskin V. (1985) Survey of Humor Research. In: Semantic Mechanisms of Humor. Synthese Language Library (Texts and Studies in Linguistics and Philosophy), vol 24. Springer, Dordrecht

Raskin,V. (1985). The Semantic Mechanisms of Humor. Dordrecht: D. Reidel Publications .

Thielemann, N. (2010). Arguing by "anekdot" - Humorous Accounts in Russian Media Interaction. Zeitschrift Für Slavische 
May Samir El Falaky

\begin{tabular}{lccc}
\hline \hline Philologie, 67(1), & $185-215$. & Retrieved & from \\
http://www.jstor.org/stable/24004090 & &
\end{tabular}

Toribio, M. (2017). Fiction in Radio Advertising and Humor: A Pragmalinguistic Analysis. AREA ABIERTA, 17(1), 99-116

Vazquez, MS. (2016). Verbal Humor Mechanisms in Twitter. CaracteresEstudios Culturales Y Criticos Se LA Esfera Digital, 5(2), 32-57. 


\section{ELLS Vol.9 No.I (256) SPU December 2018}

